\title{
Transformation Features of the Digital Economy of the Russian Federation
}

\author{
Skrypnikov A.V.* \\ Voronezh State University of Engineering Technologies \\ Voronezh, Russia \\ skrypnikovvsafe@mail.ru \\ Denisenko V.V. \\ Voronezh State University of Engineering Technologies \\ Voronezh, Russia \\ v.denisenko1@yandex.ru \\ Sapelkin R.S. \\ Voronezh State University of Engineering Technologies \\ Voronezh, Russia
}

\author{
Kozlov V.G. \\ VSAU \\ Voronezh, Russia \\ Bunina A.Y. \\ VSAU \\ Voronezh, Russia \\ Zayceva M.A. \\ Voronezh State University of Engineering Technologies \\ Voronezh, Russia
}

the competitiveness of any business operating in the Russian economy. The decrease in the economic efficiency of production activities and, as a result, the probable bankruptcy of companies, the loss of economic efficiency leads to the need to obtain financial stability of a business entity.

\section{DISCUSSION}

A similar process is observed in Russia, where the key areas of the country's innovative development are being formed, as part of the transition to the digital economy, creating the foundation for the growth of its competitiveness in the conditions of international market competition.

The relevance of scientific research on selected issues is due to the fact that the Russian Federation is undergoing a transitional stage when the development of digital technologies and economic relations in the digital environment must be decided.

The key task of government intervention in the process of forming a digital economy is the lack of the necessary conditions that accompany the digital transformation of business and industries.

The purpose of the scientific article is to analyze the process of forming the conditions for the development of the digital economy in Russia, which are actively undertaken by the state and are so necessary for the digital transformation of entrepreneurial activity.

For this purpose, in the framework of this scientific research, it is necessary to solve the following tasks:

- to analyze the general structure of national projects and budgets for their state financing during the implementation of the Digital Economy program;

- to consider the features of the implementation of national projects to create the conditions for the development of the digital economy of Russia in the field of technology, personnel and information infrastructure; 
- to list the main trends that are observed in the framework of the digital transformation of business structures.

Among the main tasks of the state program of the Russian Federation "Digital Economy" we can point out the implementation of national projects, the main of which are "Personnel for the Digital Economy", "Digital Technologies" and "Information Infrastructure".

The general structure of national projects and the budget for their state financing during the implementation of the Digital Economy program are shown in table 1.

First of all, it should be noted that 1.634 trillion rubles of funds will be spent on the implementation of the state program "Digital Economy", of which 1.099 trillion rubles go from budget funds and 0.535 trillion rubles go from extra-budgetary sources [4].

Also, in the framework of the implementation of the state program "Digital Economy" the following alternative sources of financing will be used:

- 45.5 billion rubles - the provision of universal communication services;

- 157.3 billion rubles - expenses accompanying additional financing.

Of these costs, 143.1 billion rubles will be allocated for the implementation of the national project "Personnel for the Digital Economy". New economic and technological conditions require the creation and implementation of approaches to assist citizens in mastering the key competencies of the digital economy, ensuring mass digital literacy and personalizing education. To this end, the national project "Personnel for the Digital Economy" [1] will be implemented.

The following indicators will be the goals to be achieved by 2024 [1]:

- the number of graduates of higher educational institutions with the competencies necessary for the digital economy -800 thousand people;

- digital literacy rate $-40 \%$;

- the number of specialists retrained to obtain the competencies of the digital economy -1 million people;

- ranking place in The Global Talent Competitiveness Index - around thirtieth

451.8 billion rubles will be allocated for the implementation of the national project Digital Technologies. The key objective of the project is to ensure the technological independence of the state, the possibility of commercializing domestic research and development, as well as accelerating the technological development of Russian companies and ensuring the competitiveness of the products and solutions they develop on the global market [2].
The following indicators will be the goals to be achieved by 2024 [2]:

- increase in money spent on digital development - 300 $\%$

- increase in revenue for companies using digital technology $-250 \%$;

- the number of PCT (Patient cooperation Treaty) applications for "end-to-end" digital technologies $300 \%$

772.4 billion rubles will be allocated for the implementation of the national project "Information Infrastructure". This particular area has been developed to meet the needs of the economy for the collection, storage, processing and transmission of data by domestic communication networks and infrastructure. One of the pillars of the national project is the provision of broadband access to the Internet [3].

The following indicators will be the goals to be achieved by 2024 [3]:

- rate of households having access to the Internet - $97 \%$;

- rate of state and municipal organizations using the Internet $-100 \%$;

- the number of industries in which $5 \mathrm{G}$ communication network technologies are implemented -5 ;

- Russia's share in the international market for processing and analyzing data storage databases $-5 \%$.

The implementation of the state program "Digital Economy of the Russian Federation" plays a crucial strategic role in the further socio-economic development of our country. Given current trends, digital transformation is muchneeded, and abandoning it can be followed by negative consequences.

As of today, for the second year already, the Digital Economy program has been implemented, which calls for taking measures such as allocating funding from budget funds by the Government of the Russian Federation. Among the solutions is an increase in the VAT level from January 1, 2019 (from $18 \%$ to $20 \%$ ), which should bring additional 650 billion rubles to the state budget of the country for the current year.

The key obstacle in the implementation of national projects is precisely the budget deficit and the provision of the necessary level of regulatory framework, which will stimulate the development of new digital relations.

If we analyze the goals and objectives that the Government of the Russian Federation sets when implementing national projects in the context of the transition to the digital economy, we can see that their indicators are quite realistic and coincide with global trends in the development of developed economic systems, where digital technology and the digital transformation of the state and public sectors have become a standard practice. 
TABLE I. FINANCIAL SUPPORT OF THE NATIONAL PROGRAM "DIGITAL ECONOMY"

\begin{tabular}{|c|c|c|c|c|c|c|c|c|c|}
\hline \multirow[t]{2}{*}{ № } & \multirow[t]{2}{*}{ Name of the federal project and sources of financing } & \multicolumn{7}{|c|}{$\begin{array}{c}\text { The amount of financial security by years of implementation (million } \\
\text { rubles) }\end{array}$} & \multirow[t]{2}{*}{$\begin{array}{c}\sum \text { (million } \\
\text { rubles) }\end{array}$} \\
\hline & & 2018 & 2019 & 2020 & 2021 & 2022 & 2023 & 2024 & \\
\hline 1 & "Normative regulation of the digital environment" & 220 & 297 & 297 & 307 & 265 & 265 & 266 & 1697 \\
\hline 1.1 . & provided by the federal budget & 220 & - & - & - & - & - & - & - \\
\hline 1.2 . & additional expenses of the federal budget & - & 265 & 265 & 265 & 265 & 265 & 266 & 1591 \\
\hline 1.3 . & extra-budgetary sources & - & 32 & 32 & 42 & - & - & - & 106 \\
\hline 1.4 & $\begin{array}{l}\text { expenses for the allocation of additional financing in excess of } \\
\text { the limit established by the Ministry of Finance of the Russia } \\
\text { Federation }\end{array}$ & - & - & - & - & - & - & - & - \\
\hline 2 & "Information Infrastructure" & 2391 & 94696 & 322270 & 89799 & 105859 & 89531 & 70246 & 772401 \\
\hline 2.1 . & provided by the federal budget & 2177 & 10000 & & & & & & 10000 \\
\hline 2.2 . & additional expenses of the federal budget & - & 31714 & 48121 & 67920 & 105859 & 89531 & 70246 & 413391 \\
\hline 2.3 . & extra-budgetary sources & 214 & 52982 & 274149 & 21879 & - & - & - & 349010 \\
\hline 2.4 & $\begin{array}{l}\text { expenses for the allocation of additional financing in excess of } \\
\text { the limit established by the Ministry of Finance of Russia }\end{array}$ & - & - & - & - & - & - & - & - \\
\hline 2.5 . & $\begin{array}{l}\text { provision of universal communication services (provided by the } \\
\text { Federal Law "On the Budget") }\end{array}$ & - & 13465 & 13460 & 18534 & - & - & - & 45459 \\
\hline 3 & "Personnel for the digital economy" & - & 10864 & 14886 & 24956 & 30420 & 31853 & 30109 & 143088 \\
\hline 3.1. & provided by the federal budget & - & - & - & - & - & - & - & - \\
\hline 3.2 . & additional expenses of the federal budget & - & 10499 & 13316 & 22421 & 30420 & 31853 & 30109 & 138618 \\
\hline 3.3 . & extra-budgetary sources & - & 365 & 1570 & 2535 & - & - & - & 4470 \\
\hline 3.4 & $\begin{array}{l}\text { expenses for the allocation of additional financing in excess of } \\
\text { the limit established by the Ministry of Finance of the Russia } \\
\text { Federation }\end{array}$ & - & - & - & - & - & - & - & - \\
\hline 4 & "Information Security" & 387 & 7647 & 9674 & 10080 & 1051 & 979 & 773 & 30204 \\
\hline 4.1 . & provided by the federal budget & 365 & 35 & 35 & 35 & & & & 105 \\
\hline 4.2 . & additional expenses of the federal budget & & 4780 & 5534 & 4867 & 1051 & 979 & 773 & 17984 \\
\hline 4.3. & extra-budgetary sources & 22 & 2832 & 4105 & 5178 & - & - & - & 12115 \\
\hline 4.4 . & $\begin{array}{l}\text { expenses for the allocation of additional financing in excess of } \\
\text { the limit established by the Ministry of Finance of the Russia } \\
\text { Federation }\end{array}$ & - & 10127 & 12108 & 20677 & - & - & - & 42912 \\
\hline 5 & "Digital Technologies" & 505 & 41663 & 77162 & 139313 & 67342 & 65991 & 60338 & 451809 \\
\hline 5.1 . & provided by the federal budget & 505 & & & & & & & \\
\hline 5.2. & additional expenses of the federal budget & & 21473 & 25472 & 41579 & 67342 & 65991 & 60338 & 282195 \\
\hline 5.3 . & extra-budgetary sources & & 20190 & 51690 & 97734 & & & & 169614 \\
\hline 5.4 & $\begin{array}{l}\text { expenses for the allocation of additional financing in excess of } \\
\text { the limit established by the Ministry of Finance of Russia }\end{array}$ & - & - & - & - & - & - & - & - \\
\hline 6 & "Digital Government" & 3723 & 29284 & 30916 & 40814 & 53078 & 44775 & 36838 & 235705 \\
\hline 6.1. & provided by the federal budget & 3723 & 3227 & 3096 & 3096 & & & & 9419 \\
\hline 6.2 . & additional expenses of the federal budget & & 26057 & 27820 & 37718 & 53078 & 44775 & 36838 & 226286 \\
\hline 6.3 . & extra-budgetary sources & - & - & - & - & - & - & - & - \\
\hline 6.4 . & $\begin{array}{l}\text { expenses for the allocation of additional financing in excess of } \\
\text { the limit established by the Ministry of Finance of the Russia } \\
\text { Federation }\end{array}$ & - & 4921 & 17462 & 21094 & 26769 & 22028 & 22147 & 114421 \\
\hline $\begin{array}{l}\text { In to } \\
\text { incll }\end{array}$ & $\begin{array}{l}\text { tal, according to the national program, from all sources, } \\
\text { uding: }\end{array}$ & 7226 & 212964 & 498235 & 365574 & 284784 & 255422 & 220717 & 1837696 \\
\hline fede & ral budget: & 6990 & 108050 & 123659 & 177901 & 258015 & 233394 & 198570 & 1099589 \\
\hline $\begin{array}{l}\text { antic } \\
\text { info } \\
\text { state }\end{array}$ & $\begin{array}{l}\text { cipated expenses, including the costs of ensuring the } \\
\text { rmatization of federal executive bodies and governing bodies of } \\
\text { extra-budgetary funds }\end{array}$ & 6990 & 13262 & 3131 & 3131 & - & - & - & 19524 \\
\hline addi & tional expenses & - & 94788 & 120528 & 174770 & 258015 & 233394 & 198570 & 1080065 \\
\hline $\begin{array}{l}\text { prov } \\
\text { Fed }\end{array}$ & $\begin{array}{l}\text { ision of universal communication services (provided by the } \\
\text { eral Law "On the Budget") }\end{array}$ & - & 13465 & 13460 & 18534 & - & - & - & 45459 \\
\hline $\begin{array}{l}\operatorname{expe} \\
\text { limi }\end{array}$ & $\begin{array}{l}\text { enses for the allocation of additional financing in excess of the } \\
\text { t established by the Ministry of Finance of the Russia Federation }\end{array}$ & - & 15048 & 29570 & 41771 & 26769 & 22028 & 22147 & 157333 \\
\hline extr: & a-budgetary sources & 236 & 76401 & 331546 & 127368 & 0 & 0 & 0 & 535315 \\
\hline
\end{tabular}

It should be noted that in connection with the development of the digital economy of Russia, changes are taking place within the framework of entrepreneurial structures that have acquired the following characteristics [5, p. 214]:

- appearance in production of an information factor, which has become a necessary type of resource, and no less important than financial or labor capital;
- increase in the cost of producing goods and services, an increase in the cost of production, since information and technology tend to increase their price and value, which makes the business of many enterprises less profitable; 
- reduction of transaction costs due to the use of information technology, including the fact that the number of possible financial counterparties is reduced;

- increase in the value of the labor and intellectual resources necessary in the production and consumption of information resources and technologies (trends are emerging when successful companies develop mechanisms by which they retain their employees on an ongoing basis of labor activity for a long time period);

- reduction of the level of uncertainty and the probability of the absence of a correct forecast / plan, since the use of information resources increases the accuracy of the statistical and fundamental analysis of the enterprise's production.

\section{SUMMARY}

Summing up the results of the scientific research, it is worth noting that the key task of all the analyzed national projects is to achieve the targets for improving the digital environment, digital resources, infrastructure, technologies and the economic system of Russia.

The need to implement the national project "Digital Infrastructure" is explained by the fact that without the creation of the necessary communication and information networks, the development of digital relations is impossible. The need to implement the national project "Digital Technologies" is explained by the fact that this is encouraging research and innovation, both commercial and non-profit (including state) organizations that can create those digital technologies and tools, without which it is impossible to create a digital infrastructure, economy and environment.

However, the implementation of both national projects is pointless without training the necessary human resources; this is a strategic task of "Personnel for the Digital Economy".

Thus, all national projects in the context of Russia's transition to a digital economy model are components of the overall strategy, a program to create the necessary conditions and means to realize the maximum potential of our country. Thanks to their formation and implementation, those necessary conditions are being created that is important for the Russian Federation during the transition period to a digital economy model.

\section{References}

[1] Y.A. Salikov, V.S. Mikhailiuk, "Methodological approach to the terminological analysis of the key concepts of economic security", Proc. of Voronezh State Univer. of Engineer. Technol., vol. 81, no. 2, pp. 387-392, 2019, Retrieved from: https://doi.org/ 10.20914/23101202-2019-2-387-392

[2] Deloitte (n.d.) What is Digital Economy? New York: Deloitte, Retrieved from: https://www2.deloitte.com/mt/en/pages/technology/articles/ mtwhat- is-digital-economy.html (access date: 27.01.2020).

[3] "Personnel for the digital economy", Retrieved from: https://digital.gov.ru/ru/activity/directions/866/ (access date: 27.01.2020).

[4] Y.A. Salikov, I.V. Logunova, I.V. Kablashova, "Trends in human resource management in the digital economy", Proc. of Voronezh State Univer. of Engineer. Technol., vol. 81, no. 2, pp. 393-399, 2019, Retrieved from: https://doi.org/10.20914/2310-1202-2019-2-393-399

[5] "Digital technology", Retrieved from: https://digital.gov.ru/ru /activity/ directions/ 878/ (access date: 20.01.2020).

[6] "Information infrastructure", Retrieved from: https://digital.gov.ru/ru/activity/ directions/870/ (access date: 20.01.2020).

[7] National project "Digital Economy", Retrieved from: http://static.government.ru /media/files/3b1AsVA1v3VziZip5VzAY8RTcLEbdCct.pdf (access date: 20.01.2020).

[8] E.Yu. Andieva, V.D. Filchakova, "Digital economy of the future, Industry", Appl. Mathem. and Fundam. Computer Sci., vol. 3, pp. 214-218, 2016.

[9] D. Rodrik, "Premature Deindustrialization", J. of Econ. Growth, vol. 21, no. 1, pp. 1-33, Retrieved from: http://www.nber.org/papers/w20935 (access date: 20.01.2020).

[10] World Bank, Digital Dividends: World Development Report 2016, Washington, DC, Retrieved from: http://www.worldbank.org/en/ publication/wdr2016 ((access date: 20.01.2020).

[11] I.P. Bogomolova, I.N. Vasilenko, O.M. Omelchenko, "Evaluation of the effectiveness of the formation of integrated entities on the basis of the economic-mathematical model", Proc. of Voronezh State Univer. of Engineer. Technol., vol. 2, pp. 375-381, 2018.

[12] M.V. Alikaeva, Y.N. Voloshin, Madina B. Ksanaeva, Madina R. Zakhokhova, "Problems and Prospects of Training for the Digital Economy: the Regional Dimension", pp. 547-550, 2018 [IEEE Int. Conf. Quality Management, Transport and Information Security, Information Technologies (IT\&QM\&IS)].

[13] K.G. Prokofyev, O.V. Dmitrieva, T.R. Zmyzgova, E.N. Polyakova, "Modern Engineering Education as a Key Element of Russian Technological Modernization in the Context of Digital Economy", Advances in Economics, Business and Management Research, vol. 47, pp. 652-656 [Int. Sci. Conf. Far East Con (ISCFEC 2018)].

[14] K.G. Prokofyev, E.N. Polyakova, O.V. Dmitrieva, T.R. Zmyzgova, "Digital economy of the Russian Federation as a directing factor for the development of professional personnel in the IT-sphere", pp. 90-96, November 2017 [Sci. and Pract. Conf. The concept of development of the productive forces of the Kurgan region], Kurgan.

[15] V. Mkrttchian, Y. Vertakova, "Digital Sharing Economy International", J. of Innovat. in the Digital Econ., vol. 10, pp. 43-53, 2019. 